\title{
Asepsis and Bacteriology: A Realignment of Surgery and Laboratory Science
}

\author{
THOMAS SCHLICH* \\ Department of Social Studies of Medicine, McGill University, 3647 Peel Street, Montreal, \\ Quebec, H3A 1X1, Canada
}

\begin{abstract}
This paper examines the origins of aseptic surgery in the German-speaking countries. It interprets asepsis as the outcome of a mutual realignment of surgery and laboratory science. In that process, phenomena of surgical reality were being modelled and simplified in the bacteriological laboratory so that they could be subjected to control by the researcher's hands and eyes. Once control was achieved, it was being extended to surgical practice by recreating the relevant features of the controlled laboratory environment in the surgical work place. This strategy can be seen in the adoption of Robert Koch's bacteriology by German-speaking surgeons, and the resulting technical changes of surgery, leading to a set of beliefs and practices, which eventually came to be called 'asepsis'.
\end{abstract}

\section{Keywords: Asepsis, Antisepsis, Surgery, Bacteriology}

If he were a surgeon, the laboratory scientists Louis Pasteur wrote in 1878, he would not only clean his instruments thoroughly, 'but after having cleaned my hands with the greatest of care, I would subject them to rapid flaming'. Pasteur did this in his laboratory with all objects that came into contact with his microbial cultures, in order to avoid contamination. Furthermore, he 'would use only lint, bandages and sponges previously exposed to air temperatures of $130-150^{\circ} \mathrm{C}$ and use water that had been heated to temperatures of $110-120^{\circ} \mathrm{C}^{\prime} .{ }^{1}$ These were the kinds of technologies that had enabled Pasteur to subject microorganisms to control by his eyes and hands and allowed him to make far-reaching claims about the cause of infectious diseases and ways to prevent them. In the passage above, he recommends adopting the same strategy in the surgical work environment. The power of controlling microorganisms in the laboratory was to be transferred to a specific part of the outside world - the operating room. This paper discusses how surgeons eventually followed Pasteur's advice and aligned their field of activity to laboratory science

\footnotetext{
* Email address for correspondence: thomas.schlich@mcgill.ca

I thank Christoph Gradmann, Oslo, Ulrich Tröhler, Berne and the participants of the Colloquium of the Johns Hopkins University Graduate Program in the History of Science, Medicine and Technology for commenting on previous versions of the paper. I am also grateful to Hubert Steinke, Berne, for making source material available to me.

${ }^{1}$ The translation is taken from Karel B. Absolon, Mary J. Absolon and Ralph Zientek, 'From Antisepsis to Asepsis: Louis Pasteur's Publication on "The Germ Theory and its Application to Medicine and Surgery", Review of Surgery, 27 (1970), 245-58. The original quote can be found in L. Pasteur, Théorie des germes et ses application. Lecture faite à l'Académie de Médecine (Paris, 1878), 16-17.
} 
in specific ways, as, vice versa, laboratory work on bacteriology was shaped by surgical concerns in a process of mutual realignment.

The alignment led to 'asepsis' as a new strategy of combating wound disease, replacing or supplementing the older practice of 'antisepsis'. Following its propagation by the British surgeon Joseph Lister in the 1860s, the use of antisepsis to prevent wound disease by killing living germs precipitated unprecedented changes in surgery. It went along with increased surgical success rates, heightened confidence of surgical practitioners and a considerable expansion of the surgical domain. However, it was mainly aseptic practices, not antisepsis, that made modern surgery look like it does today. Antiseptic surgery was often performed in the patient's home or in an operating theatre in front of an audience that could include hundreds of people. Most surgeons wore their street clothes while operating. Antiseptic practices varied from surgeon to surgeon and were subject to frequent changes. For a long time, antisepsis was quite controversial, especially in Lister's home country. Its connection to germ theory was even more debatable. Many surgeons came to adopt elements of antisepsis in their practical work, but at the same time they rejected the underlying assumption that its effect was due to the elimination of living infectious agents. Up until the 1880s/90s there was no general agreement about the causal role of germs in wound infection. The majority of surgeons thought that microorganisms were unstable in their characteristics, unspecific in terms of their pathogenic effect and in general hard to control. The relationship between antiseptic practices and their scientific justification was thus chronically unstable. Proponents of antisepsis even tended towards a conscious strategy of separating the practice from its theoretical implications by stressing its results rather than its rationale. ${ }^{2}$ Lister and other advocates of antiseptic surgery did conduct laboratory experiments, but these experiments did not form the core of their argument. Nor was laboratory science used systematically as a resource for conceptual or practical innovation. All in all, there was no firm alignment of laboratory science and surgery, neither rhetorically nor practically. ${ }^{3}$

In the course of the last quarter of the nineteenth century, the majority of surgeons adopted 'living-germ theories of sepsis' and started 'using antiseptic methods', ${ }^{4}$ as historian Michael Worboys notes. At that time, antiseptic practices became much broader and inclusive than before. In Britain, Lister's followers were able to appropriate the term 'antisepsis' and expand its meaning, up to point, as Christopher Lawrence and Richard Dixey claim, to encompass all 'successful surgery'. ${ }^{5}$ Eventually, they also laid claim to the newly emerging term 'asepsis'. The justification was that Lister had suggested excluding

\footnotetext{
${ }^{2}$ Michael Worboys, Spreading Germs. Disease Theories and Medical Practice in Britain, 1865-1900 (Cambridge: Cambridge University Press, 2000), 156; Anna Greenwood, 'Lawson Tait and Opposition to Germ Theory: Defining Science in Surgical Practice', Journal of the History of Medicine and Allied Sciences, 53 (1998), 99-131.

3 This was true for Britain, see Worboys, op. cit. (note 2), 73-107, 150-92, for the US, see Thomas P. Gariepy, 'The Introduction and Acceptance of Listerian Antisepsis in the United States', Journal of the History of Medicine and Allied Sciences, 49 (1994), 167-206, but also for Germany, see eg. the most important German textbook for antisepsis, Johann Nepomuk Nussbaum, Leitfaden zur Antiseptischen Wundbehandlung, insbesonders zur Lister'schen Methode für seine Schüler und für praktische Ärzte (Stuttgart: Enke, 1879), and the papers of the main supporter of Lister's antisepsis in Germany, Richard Volkmann (eg. his 'Ueber den antiseptischen Occlusivverband und seinen Einfluss auf den Heilungsprocess der Wunden', in Richard Volkmann (ed.), Sammlung klinischer Vorträge, Series on Surgery, vol. II (Leipzig: Breitkopf \& Härtel, 1875)).

${ }^{4}$ Worboys, op. cit. (note 2), 150.

${ }^{5}$ Christopher Lawrence and Richard Dixey, 'Practicing on principle: Joseph Lister and the germ theories of disease', in Christopher Lawrence (ed.), Medical Theory, Surgical Practice: Studies in the History of Surgery (London and New York: Routledge, 1992), 153-215: 206-7.
} 
septic agents from the wound from the start. ${ }^{6}$ The Listerians were one of three groups of surgeons in Britain who claimed to be the inventors and custodians of germ-free aseptic surgery, in addition to the so-called Cleanliness School, which advocated strict cleanliness without using germ theory, and the new German-inspired group of aseptic surgeons. ${ }^{7}$ This paper deals with this last kind of asepsis, as it emerged in the German-speaking countries in the 1880s and 90s. Its proponents rejected chemical antiseptics and methodically based their procedures on Robert Koch's laboratory methods. ${ }^{8}$

By the 1890s most of the practices and theories of avoiding septic wound complications started to be called aseptic, rather than antiseptic. ${ }^{9}$ Considering the spread of the term, 'it could be plausibly argued that antisepsis was never accepted; asepsis instead won the day', as Thomas Gariepy claims. ${ }^{10}$ However, such changes in language did not necessarily correlate with clear-cut theoretical and practical changes. The boundary between antisepsis and asepsis varied in different contexts and at different times. Historians have traditionally interpreted asepsis as just a further developed version of antisepsis and ascribed to Lister a decisive role for both. This interpretation has been up for discussion since several revisionist accounts have stressed the discontinuity between the two techniques. ${ }^{11}$ The current state of affairs seems to be that the answer lies between the two, as T.H. Pennington has stated. ${ }^{12}$ The most recent comprehensive account comes from Worboys, who tends to emphasise continuity, because both techniques share the common ideal of a germfree environment around the wound or the patient and because they were widely used in parallel. ${ }^{13}$

In the German context, as we will see, surgeons presented asepsis sometimes as an elaboration of antisepsis, or, depending on their rhetorical strategies, as a new approach. Especially in the beginning, the advocates of asepsis often emphasised the novelty of the new technique. Later they tended to stress continuity in order to take advantage of the prestigious Lister pedigree. Thus, the use of the term asepsis varied according to context. I will show how in the German-speaking world the characteristic set of beliefs and practices this paper is focused on was still subsumed under the term 'antisepsis' when it was first introduced. Only around 1890 did its proponents start calling it 'asepsis'.

In my analysis I examine the relationship of bacteriology and surgery as a process of mutual realignment around the common interest in controlling life processes. This alignment was consequential for both parties involved. In his manual Antisepsis and Antiseptics of 1895 Charles Buchanan called modern bacteriology 'the legitimate offspring

\footnotetext{
${ }^{6}$ Worboys, op. cit. (note 2), 168, 174, 183.

${ }^{7}$ Worboys, op. cit. (note 2), 186.

${ }^{8} \mathrm{Eg}$. Worboys, op. cit. (note 2), 151. In Britain, there were attempts at emulating the German realignment of surgery and laboratory science in the $1880 \mathrm{~s}$ and $90 \mathrm{~s}$, but they remained fragmentary, see Worboys, op. cit. (note 2), 170-86. Similarly in the US, see Gert Brieger, 'American Surgery and the Germ Theory of Disease', Bulletin of the History of Medicine, 40 (1966), 135-45: 142-5; Gariepy, op. cit. (note 3), 194-201.

${ }^{9}$ On Britain, see Worboys, op. cit. (note 2), 172-92; on the US, see Brieger, ibid., 140.

${ }^{10}$ Gariepy, op. cit. (note 3), 202-6: quote on p. 205.

${ }^{11}$ N.J. Fox, 'Scientific Theory Choice and Social Structure: The Case of Joseph Lister's Antisepsis, Humoral Theory and Asepsis', History of Science, 26 (1988), 367-97; Lawrence and Dixey, op. cit. (note 5); Lindsay Granshaw, “Upon this principle I have based a practice": the development of antisepsis in Britain, 1867-90', in John V. Pickstone (ed.), Medical Innovations in Historical Perspective (New York: St. Martin's Press, 1992), 17-46; T.H. Pennington, 'Listerism, its Decline and its Persistence: The Introduction of Aseptic Surgical Techniques in Three British Teaching Hospitals, 1890-99', Medical History, 39 (1995), 35-60: 36-9, 42-3.

12 Pennington, ibid., 36.

13 Worboys, op. cit. (note 2), 186-7, 191.
} 
of antiseptic surgery', ${ }^{14}$ and surgical concerns were indeed constitutive for bacteriology from the start. For surgeons, on their part, the alignment with laboratory science was associated with the prospect of improving surgical outcomes. Surgeons could hope to avail themselves of the special strengths of the laboratory. These strengths were based on the strategy of reducing complexity and enabling control in a place and under circumstances where things can be tried out, where researchers can make mistakes and learn from them, and only move to the world outside of the laboratory once control had been achieved. ${ }^{15}$ By exploring the mutual influence of bacteriology and surgery, this paper contributes to the history of surgery but also to the history of laboratory science. It looks at how the laboratory 'has been made to be important' ${ }^{16}$ in surgery and thus aims at situating it in specific contexts outside laboratory science itself, in line with Graeme Gooday's recent claim that 'it is generally in arenas outside the laboratory that one finds debates about what a laboratory should be, whether it is needed, by whom and for what purposes'. ${ }^{17}$

In what follows, I first look at Koch's bacteriology, especially his surgically relevant study on wound infection. I characterise Koch's approach as a control strategy and look at how surgical concerns were part of his project early on. I then examine how surgeons in the German-speaking countries adopted Koch's approach and incorporated bacteriology into their field. I describe how surgeons tried out the new techniques, how they appropriated, modified and sophisticated them with the help of bacteriologists or in their own bacteriological laboratories, how this approach, which was now called 'asepsis', went through a period of crisis and was finally adapted to a more complex view of infection. The adoption of laboratory principles changed surgical practices and expectations so that at the end of the nineteenth century, surgical operations had become more thorough, precise and time-consuming, but also more daring and more sophisticated than ever before. Innovative surgeons showed a greater affinity to laboratory science, as they were taking up physiology in another alignment, which led to new procedures such as organ transplantation.

\section{Robert Koch's Bacteriology and Surgery}

Pasteur's suggestion of adopting laboratory practices in surgery was taken up by a new generation of surgeons. However, it was not the French scientist who became the model of this reorientation process. Instead Robert Koch in Germany provided the crucial point of reference for these surgeons. It is not by chance that the realignment of the two fields originated in the German lands, where university or State-run laboratories had become a generally acknowledged source of new medical knowledge. ${ }^{18}$

\footnotetext{
${ }^{14}$ Brieger, op. cit. (note 8), 145. On Buchanan, see also Gariepy, op. cit. (note 3), 203-4.

${ }^{15}$ Bruno Latour, 'Give me a laboratory and I will raise the world', in Karin D. Knorr-Cetina and Micheal Mulkay (eds), Science Observed. Perspectives on the Social Study of Science (London, Beverly Hills and New Delhi: Sage, 1983), 141-70; Joseph Rouse, Knowledge and Power (Ithaca and London: Cornell University Press, 1987), 95-111, calls the laboratory an 'artificial microworld'. For this line of argument in connection with surgery, see also Thomas Schlich, 'Surgery, Science and Modernity: Operating Rooms and Laboratories as Spaces of Control', History of Science, 45 (2007), 231-56.

${ }^{16}$ Greenwood, op. cit. (note 2), 103.

${ }^{17}$ Graeme Gooday, 'Placing or Replacing the Laboratory in the History of Science?' Isis, 99 (2008), 783-95: 786.

18 John V. Pickstone, 'Ways of Knowing: Towards a Historical Sociology of Science, Technology and Medicine', British Journal for the History of Science, 26 (1993), 433-58; Arleen Tuchman, Science, Medicine, and the State in Germany: The Case of Baden, 1815-1871 (New York: Oxford University Press, 1993); Timothy Lenoir, 'Laboratories, medicine and public life in Germany, 1830-1849: ideological roots of the institutional revolution',
} 
Koch's career is a typical example of the German pattern. ${ }^{19}$ His trajectory started in the 1870s, when the problem of wound infection claimed a special place in the emerging field of bacteriology. It was, as historian Christoph Gradmann, has phrased it, the problem of medical bacteriology par excellence. ${ }^{20}$ Between the 1840 s and 1870 s, the increasing use of culture and visualization methods and, above all, animal experiments had turned research on infectious disease into a science that was based in the laboratory. Scientists hoped to demonstrate causal relationships between microorganisms and disease in this specifically designed space of control. The advent of new culture and staining methods in the 1870s enabled them to distinguish different species of bacteria and relate them to specific diseases, following the approach propagated by the German botanist Ferdinand Cohn (1828-98). However, belief in the constancy of bacterial species and their specific role in causing disease was not the majority opinion at the beginning of the 1870s. Most interestingly for surgery, Theodor Billroth (1826-94) in Vienna, one of the most influential surgeons of his time, claimed in his 1874 book on the Coccobacteria septica that bacteria occurring in putrid wounds were variants of ubiquitous fungous creatures and, even more importantly, that they were not the cause but the effect of septic wound complications. ${ }^{21}$

There was, however, a vocal minority of doctors who claimed a causal role for specific bacteria in wound disease. In the Franco-Prussian war of 1871/72, the pathologist Edwin Klebs (1834-1913) had described the constant occurrence of bacteria in purulent gun shot wounds. He claimed that these specific organisms were not only present, but that they were the cause of specific wound diseases. Their causal role, he proposed, could be proven by their regular presence and the ability to use them to induce the same wound disease in healthy test animals. ${ }^{22}$ In 1872 the physician Casimir Davaine (1812-82) in France furnished more evidence for the causal role of living organisms when he transmitted septicaemia in rabbits with very small amounts of bacteria. Despite these arguments, however, by the mid-1870s the question was still unresolved. The crux of the matter seemed to be that the presence of particular bacterial species in the wound could not be brought into a proven relationship with the aetiology of wound disease. ${ }^{23}$

This was the situation when Koch took up the topic. Koch had adopted Cohn's approach and tried to make it useful for medical purposes. Following up on Klebs' work, he turned to the kind of infections that usually complicate injuries and operation wounds, as he wrote in 1878 , thus targeting his project specifically at surgeons. ${ }^{24}$ In his previous work, on the aetiology of anthrax, Koch had already provided convincing arguments in favour of the specific causation of infectious diseases. His research on wound infections was his next major foray into the field. It contributed significantly to the shaping and acceptance of

in Andrew Cunningham and Perry Williams (eds), The Laboratory Revolution in Medicine (Cambridge: Cambridge University Press, 1992), 14-71; Richard L. Kremer, 'Building institutes for physiology in Prussia, 1836-1846: contexts, interests, and rhetoric', in Cunningham and Perry (eds), idem, 72-109.

${ }^{19}$ William F. Bynum, Science and the Practice of Medicine in the Nineteenth Century (Cambridge: Cambridge University Press, 1994), 95-103.

${ }^{20}$ Christoph Gradmann, Krankheit im Labor. Robert Koch und die medizinische Bakteriologie (Göttingen: Wallstein, 2005), 81.

${ }^{21}$ William Bulloch, The History of Bacteriology (New York: Dover, 1938), 198; Gradmann, ibid., 59-83.

${ }^{22}$ Silvia Berger, Bakterien in Krieg und Frieden. Eine Geschichte der medizinischen Bakteriologie in Deutschland 1890-1933 (Göttingen: Wallstein, 2009), 35-6.

${ }^{23}$ Gradmann, op. cit. (note 20), 59-83.

24 Robert Koch, Untersuchungen über die Aetiologie der Wundinfectionskrankheiten (Leipzig: F.C.W. Vogel, 1878), 5; Berger, op. cit. (note 22), 39. 


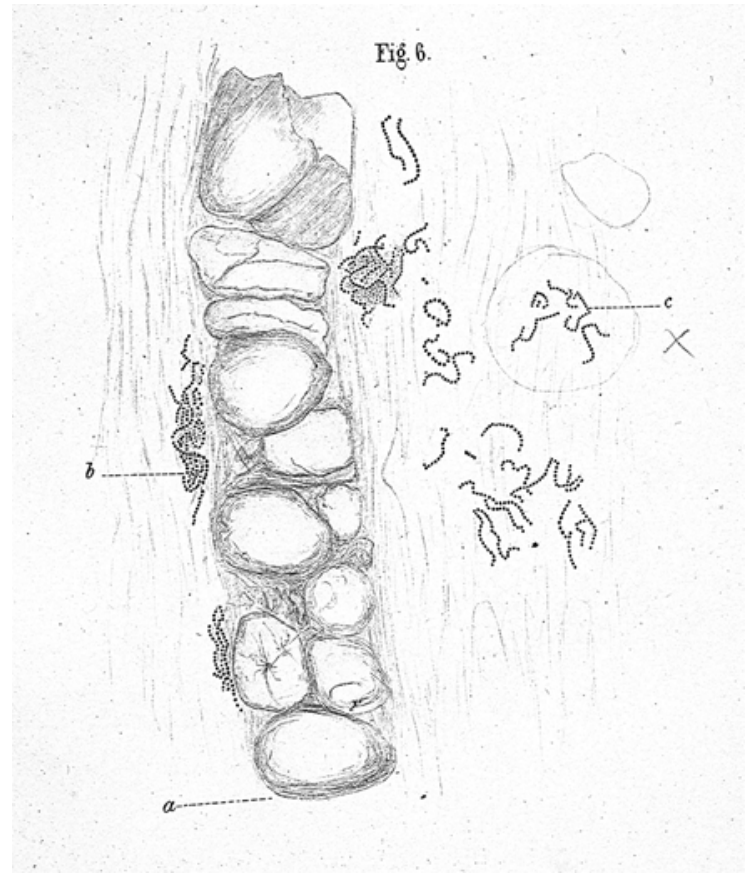

Figure 1: Micrococci in a rabbit's ear, showing the invasion of the animal tissue by microorganisms. ${ }^{25}$

his bacteriological research method. Through the injection of 'putrid fluids' into mice he elicited six different wound diseases and linked them to specific, morphologically identifiable bacteria. ${ }^{26}$

Figure 1 shows how Koch presented his findings to his readers. In this microscopic image from his 1878 publication one can see, according to the author's instructions, marked with '(b)' chain-shaped microbes (micrococci) in clusters, and under '(c)' the same organism in single formations, whereas '(a)' refers to cartilage cells of a rabbit's ear, of which the drawing shows a cross section. The drawing makes it evident to the reader's eyes, Koch claims, how the bacteria have invaded the animal's organism in a generalized wound infection after previous inoculation with infectious microorganisms. ${ }^{27}$ In order to distinguish bacterial species and assign them to specific infectious diseases Koch first inoculated another animal with infectious substance. The bacteria multiplied in that new organism and could then be transferred again. In this way Koch used the sequential passage through animals (combined with microscopic control) to separate specific bacteria from others. This strategy reflects his understanding of infectious disease as essentially an invasion of bacteria, which spread in the animal body like in a culture medium ${ }^{28}-\mathrm{a}$ view that became important in surgery later on. The rabbit ear image shows a late stage in the sequential transmission process in which the infectious agent has been concentrated,

${ }^{25}$ Robert Koch, Untersuchungen über die Aetiologie der Wundinfectionskrankheiten (Leipzig: F.C.W. Vogel, 1878 ), figure 6 in the appendix. Courtesy of the Osler Library, McGill University, Montreal, Canada.

${ }^{26}$ Berger, op. cit. (note 22), 39.

${ }^{27}$ Koch, op. cit. (note 24), 4.

${ }^{28}$ Gradmann, op. cit. (note 20), 97-103. 
purified and made visually identifiable in its current host organism. An image like this was the outcome of a controlled sequence of selective representation procedures. ${ }^{29}$

The proof of the causal role of bacteria in wound infection was thus the outcome of a thoroughly controlled procedure, in which Koch had to make sure that his laboratory animals were only infected with one particular agent. In the course of the necessary manipulations, microorganisms needed to be kept in particular places and out of others, a precaution that required utmost corporeal discipline in handling samples, cultures and instruments. His laboratory methods enabled Koch to subject putative infectious agents and their host organisms to control by his hands and eyes, as Bruno Latour would put it, ${ }^{30}$ up to a point where he could literally show to his readers the causal role of microbes in wound infection on a small piece of paper that could even be reproduced by the printing press and widely distributed. His new methods allowed Koch to forge the causal link between identifiable microorganisms and specific wound diseases. ${ }^{31}$ Even though Koch's wound disease work was limited to artificial septic diseases in animals, he had established a convincing laboratory model for human wound infection, which could be used for further knowledge production. ${ }^{32}$ Koch's work on wound infection was to provide 'the point of departure for a process of redefining infectious disease through medical bacteriology, which was to take place in the subsequent decades', as Gradmann states, ${ }^{33}$ and which gave the laboratory a privileged place in medical and surgical innovation.

In his wound infection work, Koch's experimental arrangements were still unstable. His methodology stabilised into its 'classic' form in his work on tuberculosis around 1882. It was subsequently canonised by one of his collaborators, Friedrich Loeffler (1852-1915), as 'Koch's postulates'. ${ }^{34}$ The postulates set up the conditions that have to be fulfilled for proving the causal relationship between a disease and a microorganism: The microorganism has to be constantly demonstrable in the sick organism. It has to be isolated, identified and cultured outside that original organism. Finally, it has to be inoculated into a healthy organism where it has to elicit the original disease. Fulfilment of these criteria counted as the proof for the specific causal effect of a pathogen.

While in his work on anthrax and wound infection Koch had used the passage through animal organisms as a way of obtaining pure cultures, ${ }^{35}$ in his mature work Koch further increased his control and produced pure cultures of infectious agents outside of animal bodies. The introduction of solid culture media for creating these pure cultures was one of Koch's most significant contributions to bacteriological methodology. The culture medium consisted of a nutrition fluid that was poured into a shallow Petri dish and solidified with the help of gelatine or agar-agar. A small amount of the bacteria-containing fluid was spread out on this solid surface, where separate bacterial colonies consisting of just one

\footnotetext{
${ }^{29}$ Koch, op. cit. (note 24), 1-9. On the representation techniques in more detail, see Thomas Schlich, 'Linking Cause and Disease in the Laboratory: Robert Koch's Method of Superimposing Visual and "Functional" Representations of Bacteria', History and Philosophy of the Life Sciences, 22 (2000), 71-88.

30 Bruno Latour, 'Visualization and Cognition: Thinking with Eyes and Hands', Knowledge and Society: Studies in the Sociology of Culture Past and Present, 6 (1986), 1-40.

${ }^{31}$ Koch, op. cit. (note 24), 27-8; Gradmann, op. cit. (note 20), 84-90.

32 Gradmann, op. cit. (note 20), 84-90; Koch, op. cit. (note 24), 3. The gap was filled by Alexander Ogston, at that time assistant surgeon to the Aberdeen Royal Infirmary. Following Koch's technical methods exactly, he examined abscesses in humans and determined their infective agents, see Bulloch, op. cit. (note 21), 149.

33 Gradmann, op. cit. (note 20), 90; see also 91-103.

34 On the history of the postulates, see Christoph Gradmann, 'Alles eine Frage der Methode. Zur Historizität der Kochschen Postulate 1840-2000', Medizinhistorisches Journal, 43 (2008), 121-48.

35 Bulloch, op. cit. (note 21), 226.
} 
species would grow. ${ }^{36}$ The decisive advantage was that, as Koch pointed out, the solid culture 'prevents that the different species get mixed up' and enables constant survey of the colonies, whereas the fluid medium 'exhibited a picture of a confusing mix of forms and shapes in microscopic examination'. ${ }^{37}$ The hitherto unruly and confusing world of bacteria could thus be easily subjected to the researcher's manual and visual control. This desire for perfect order and control was shared, as we will see, by German-language surgeons. ${ }^{38}$

Two years after the publication of his wound infections study, Koch obtained a new position as a senior researcher at the recently founded Imperial Health Office in Berlin. The Office had a laboratory especially set up for him and included a research group of young doctors working on infectious disease. The position allowed Koch to work with improved experimental methods. Here, he was able to use his reductionist approach to concentrate resources that had been scattered in various fields. ${ }^{39}$ Early German bacteriology assumed that the body was germ free and that its boundaries - if not violated by injury - were impermeable. Like the culture media that were used in the laboratory, the shielded body behaved passively towards pathogenic bacteria. ${ }^{40}$ This view is also embodied in Figure 1 of the bacterial invasion of the host body. Surgery, of course, would violate the sealed boundaries and leave the body open to such bacterial invasion.

Conceptually, Koch followed the principle of aetiological specificity. He attributed each disease to a clearly distinguishable and non-changing bacterial species and thus realigned clinical nosology with bacterial taxonomy, as suggested by Cohn and by Klebs before. The clear order allowed for a new degree of scientific certainty and effective prophylaxis and therapy, Koch claimed. ${ }^{41}$ The link between species constancy, causal specificity and practical control comes out in a paper that Koch's collaborator at the Imperial Health Office, Georg Gaffky (1850-1918), wrote in 1881 on the surgical topic of septicaemia. If harmless bacteria were able to transmute into dangerous ones and back at any time, Gaffky posited, the chances of controlling the diseases they caused would be very low. Control was only viable if the species of the microorganisms involved were constant and if they had a specific causal link to wound complications. ${ }^{42}$ But Gaffky's paper also makes clear that the identification of stable and specific pathogens in turn depended in the ability to control microorganisms in the laboratory, for example through the 'control of sowing and of harvesting bacteria', as he writes. This required very thorough and sophisticated techniques. The slightest flaw would spoil such an experiment and destroy the causal attribution. $^{43}$

Kochian bacteriology was not so much about theories. Instead it was based on sets of practices, which always stood in close relationship to some medical use. Thus, with his staining and culture techniques Koch offered surgeons a toolset for bacteriological

\footnotetext{
${ }^{36}$ Robert Koch, 'Zur Untersuchung von pathogenen Organismen', Mittheilungen aus dem Kaiserlichen Gesundheitsamte, 1 (1881), 1-48: 28.

${ }^{37}$ Ibid., 22, 25.

${ }^{38}$ Interestingly the emphasis on order and control was characteristic not only for bacteriology and surgery, but also for German military concepts of the time, Berger, op. cit. (note 22), 74.

${ }^{39}$ Berger, op. cit. (note 22), 45.

${ }^{40}$ Berger, op. cit. (note 22), 60.

${ }^{41}$ Gradmann, op. cit. (note 20), 102; Koch, op. cit. (note 24), 26-7.

${ }^{42}$ Georg Gaffky, 'Experimentell erzeugte Septicämie mit Rücksicht auf progressive Virulenz und accommodative Züchtung', Mittheilungen aus dem Kaiserlichen Gesundheitsamte, 1 (1881), 80-133: 82. On the shaping of Koch's concept of specificity by medical concerns, see Olga Amsterdamska, 'Medical and Biological Constraints: Early Research on Variation in Bacteriology', Social Studies of Science, 17 (1987), 657-87.

43 ،... . die Controle der Aussaat sowohl, wie der Ernte ...' Gaffky, ibid., citation: 127, see also 116-7, 133.
} 
examination of all kinds of objects, making 'the world of the invisible"44 observable and thus - that's the promise - potentially controllable for surgeons. Koch did not hesitate to use his new means of control for further surgically important studies. In 1881 he applied his bacteriological toolset to investigate the efficacy of different antiseptics. Most importantly, he found that carbolic acid, the substance commonly used in antisepsis, was much less effective than previously assumed. In fact, it was almost useless for killing germs. In the form of a spray, as used by Lister, for example, it had no effect whatsoever in the laboratory tests. The low efficacy of carbolic acid explained, as Koch wrote, why one could often find bacteria underneath a Lister dressing. ${ }^{45}$ Other frequently used disinfectants fared no better when tested under normal work conditions. Koch's finding caused quite a stir among surgeons, who hurried to replace carbolic acid by other agents, mostly, like Lister, by corrosive sublimate, which Koch had shown to be very effective in killing bacteria. ${ }^{46}$ In another bacteriological study of surgical relevance Koch, Gaffky and Loeffler looked at various methods of heat sterilisation, which was originally a laboratory method used to stop contamination with unwanted microorganisms, and found hot water vapour to be the most effective technique. ${ }^{47}$

All of this was not lost on surgeons. For them, Koch's conversion of germ theory into a series of demonstrable bacterial aetiologies made the adoption of antibacterial measures difficult to resist, as Worboys argues for Britain. ${ }^{48}$ In the process, however, these antibacterial measures took on the form of what came to be called 'asepsis' rather than antisepsis. It is not by chance that aseptic surgery spread in the German-speaking world in exactly the same time period, the 1880s and 1890s, when Koch's approach spread and his students took on professorships at the German-language universities. ${ }^{49}$

\section{A Programme of Realigning Surgery and Bacteriology}

Anti-germ procedures were not new to German-language surgeons in the late 1870s. In Germany Lister's ideas enjoyed particular popularity and Listerians 'were working with the grain of advanced medical science rather than against it', as Worboys has put it. ${ }^{50}$ With the gradual adoption of Koch's bacteriology, however, German surgeons started distancing themselves from Lister's practices and came to follow what they later called 'asepsis' as their declared strategy. A version of that strategy was first proposed by Gustav Adolf Neuber (1850-1932), who also seems to have been the first to use the term in the German context. ${ }^{51}$ Neuber rejected the use of antiseptic substances, particularly in wounds and dressings, and advocated a strict regime of anti-contamination instead. He called this

\footnotetext{
${ }^{44}$ Herr Carl Langenstein (Hamburg), 'Diskussionsbeitrag', Verhandlungen der Deutschen Gesellschaft für Chirurgie, 27 (1898), 16-7: 16.

45 Robert Koch, 'Ueber Desinfection', Mittheilungen aus dem Kaiserlichen Gesundheitsamte, 1 (1881), 234-83: 352.

${ }^{46}$ Pennington, op. cit. (note 11), 38.

${ }^{47}$ Dr Robert Koch, Dr G. Gaffky and Dr F. Loeffler, 'Versuche über die Verwerthbarkeit heisser Wasserdämpfe zu Desinfectionszwecken', Mittheilungen aus dem Kaiserlichen Gesundheitsamte, 1 (1881), 322-40. On the use of heat sterilisation as laboratory method, see eg. Koch, op. cit. (note 35), 17.

48 Worboys, op. cit. (note 2), 182.

49 About Koch's students, see Berger, op. cit. (note 22), 12.

${ }^{50}$ Worboys, op. cit. (note 2), 98-9.

51 Gustav Neuber, Die aseptische Wundbehandlung in meinen Privat-Hospitälern (Kiel: Lipius \& Tischler, 1886); Georg Ernst Konjetzny and Edward Heits, Gustav Adolf Neuber und die Asepsis (Stuttgart: Enke, 1950). Mikulicz attributed the beginning of asepsis to Neuber, but its development into a generally useable method he saw as a collective accomplishment, in which Bergmann and his student Schimmelbusch played a prominent
} 
strategy 'asepsis' to distance himself from Lister and his use of antiseptic chemicals. His system can be interpreted as a variety of the clean surgery concepts that existed in Britain along with Listerism. In retrospect Neuber himself pointed to that parallel. ${ }^{52}$ Like his British counterparts, the German surgeon did not base his practices on bacteriological research - he did not have a laboratory and he insisted that Robert Koch's bacteriology was not the source of his approach. Neuber never gained much influence among his colleagues. He first developed his system in a professionally subordinated position while he was assistant surgeon to the eminent Friedrich von Esmarch (1823-1908) at the University Hospital in Kiel. Subsequently he set up his own private hospital in the city, where he put his ideas into practice. That Neuber was the first to have proposed 'asepsis' in Germany was generally acknowledged, but it was also clear that the large-scale adoption of the new approach was a different project, initiated elsewhere and in a very different form, namely in conjunction with a realignment of surgery and laboratory science.

The most influential proponent of the realignment strategy was Ernst von Bergmann (1836-1907). Bergmann's interest in the topic went back to the 1860 s when he conducted important experimental research on the causation of wound disease by chemical substances. He subsequently converted to the Listerian concept of living germs and practised antiseptic surgery as chief surgeon of the relatively marginal university hospitals of Dorpat and Würzburg. ${ }^{53}$ His appointment as head surgeon of the University Clinic at the Ziegelstrasse in Berlin in 1882 put him, a largely unknown entity in the field, in a key position of German academic surgery. He came to Berlin with a commitment to make laboratory science the basis of surgery - a programme that he explicitly linked to the idea of control in his inauguration speech. Before the introduction of antisepsis, he explained, surgeons had only controlled the 'bloody act' of the operation itself, things like the size of the cut, the quality of haemostasis and so on. Once the act was over, the surgeon, not knowing if and why his patient would die after the operation, was as powerless as the monk and stonecutter Jacque Baulieu of Franche Comté in the seventeenth century, who told his patients 'l'opération est achevée - Dieu vous guérisse'. Now, by contrast, surgeons were no longer subject to the vagaries of chance. Knowledge of the cause of the 'so-called accidental wound diseases' had given them the power to actively avert damage to their patients and assume full responsibility of their operations' ultimate outcome. Based on the trust in his skills and capabilities, the modern surgeon was now in a position to try out his newly acquired strength. ${ }^{54}$

The modern surgeon's new strength, Bergmann claimed, derived from the laboratory. It was animal experimentation, not clinical experience, that had shown surgeons how to make wounds heal without danger. This is why laboratory research was an indispensable part of up-to-date surgery. In order to overcome wound disease, surgeons needed to apply Koch's theory of specific aetiology and the experimental methods that came with it. It was true that clinical observation had already pointed to an infectious aetiology of the problem.

role, see J. Mikulicz, 'Ueber der neuesten Bestrebungen, die aseptische Wundbehandlung zu vervollkommnen', Verhandlungen der deutschen Gesellschaft für Chirurgie, 27 (1898), 1-37: 1-2.

52 See eg. Granshaw, op. cit. (note 11), 27-40. On Neuber's claim of British lineage for his approach, see G. Neuber, 'Erfolge der aseptischen Wundbehandlung', Verhandlungen der Deutschen Gesellschaft für Chirurgie, 32, II (1903), 264-80: 271-2.

53 Arend Buchholz, Ernst von Bergmann (Leipzig: F.C.W. Vogel, 1911), 245, 333, 413; Bulloch, op. cit. (note 21), 133-4.

${ }^{54}$ For this and the following, see Ernst von Bergmann, 'Die Gruppierung der Wundkrankheiten', Berliner klinische Wochenschrift, 19 (1882), 677-9, 701-3: 678. On Bergmann's status as an unknown surgeon at the time of his appointment, see Carl Ludwig Schleich, Besonnte Vergangenheit (Berlin: Rowohlt, 1921), 168. 
The actual proof of causality, however, could only be accomplished under the controlled conditions of the experimental laboratory. There, diseases could be produced in healthy organisms by inoculating them with specific bacteria. As opposed to Lister's approach, the new kind of antisepsis was based on the knowledge of specific aetiology as taught by Koch. Bergmann distanced himself from Lister by pointing out that the British surgeon had not used the laboratory as a resource. Lister's system was based on the assumption, not on the proof, of the bacterial aetiology of wound diseases. Considering that Lister's imperfect approach had already led to an enormous improvement of surgical results, how much more could be expected from an accurate and precise analysis through the new bacteriology!

In another programmatic speech, at the important Meeting of German Scientists and Physicians in Eisenach in the same year, Bergmann distanced himself further from his Listerian colleagues. ${ }^{55} \mathrm{He}$ rejected the way Lister and his adherents had deduced the scientific accuracy of germ theory from the improved surgical results reached through antisepsis. That was mere conjecture, he argued. A scientific hypothesis should never be tested through clinical observations. Only laboratory science would provide the means to establish order in the messiness of the clinical world and give clinicians enough certainty to fulfil their practical tasks with confidence. The identification of a specific pathogenic agent through experimental science would lead to the 'clear and precise task' of eliminating exactly that agent and test the effect of antiseptic substances on it. ${ }^{56}$ 'A problem that is clearly expressed will be soon followed by a succinct and satisfactory solution', ${ }^{57}$ he declared. He thus linked the concept of specific aetiology with the promise of efficiency in the same way Koch and his collaborators did.

Bergmann cited Koch's recent study on disinfectants and asserted how the 'fact that even under the most successful Lister dressing cocci and bacteria are teeming is enough to show how far we are still away from our ideal of perfect wound disinfection' ${ }^{58}$ The study showed that measures against wound infection could no longer be measured just by clinical success. They had to be evaluated in the test tube and the incubator. The standards of evaluation had to be shifted from the clinic to the laboratory. Surgeons had to become scientists and adopt the natural scientist's mode of operation - a strategy that had already started to produce a new dynamic, Bergmann claimed:

We live in the hope that antiseptic wound treatment is presently approaching multiple improvements since our knowledge about the processes in wound infection is, even though it has just been called to life, already in a process of advancement. The more we advance in knowledge, the more will we advance in capability. ${ }^{59}$

At that time, Bergmann presented his programme as an attempt to put 'antisepsis', as it was first initiated by Lister, on a new footing. He did not use the term 'asepsis' in this context.

\footnotetext{
55 The annual 'Versammlung Deutscher Naturforscher und Ärzte' was an important and prestigious forum for presentations to a larger elite public in the German-speaking world of the nineteenth century. Bergmann's speech was subsequently published in the most important German non-specialised medical journal: Ernst von Bergmann, 'Ueber antiseptische Wundbehandlung', Deutsche medizinische Wochenschrift, 8 (1882), 559-61, 571-2. On the programmatic function of this speech, see Buchholz, op. cit. (note 52), 419.

56 Bergmann, ibid., 571.

57 Bergmann, ibid., 571.

58 Bergmann, ibid., 571.

59 Bergmann, ibid., 572.
} 


\section{The Programme in Practice: Bacteriological Research in Surgery}

As one sign of progress Bergmann pointed to the discovery of the aetiology of erysipelas, one of the common wound diseases, which had been made in the same year by his assistant Friedrich Fehleisen (1854-1924). ${ }^{60}$ To make this discovery, the young surgeon had exactly followed Koch's procedures as formalised in the famous postulates. He had first demonstrated the regular occurrence of the same bacterial species in the affected tissues of diseased animals. Then he grew these bacteria in a pure culture outside the animal organism for the purpose of, as he wrote, 'proving causality with absolute certainty', which 'was unthinkable without using a pure culture'. He produced fourteen generations of pure bacteria within two months. When he inoculated these pure bacteria into rabbits he found that the microscopic image of the animals' affected tissues perfectly matched the findings in humans with erysipelas. Moreover, the course of the artificially induced disease was absolutely analogous to the human cases. Fehleisen was in the lucky position to inoculate human subjects with the infectious agent in order to show that his results applied to humans too. He was able to do so, because, at that time, doctors thought an erysipelas infection helped to cure cancer. Fehleisen infected cancer patients with bacteria from his pure cultures as part of their therapy and found that these patients indeed developed erysipelas, thus closing the argumentative circle and completing his discovery. Having proven the aetiological relationship between bacteria and disease in this way, the surgeon also tested the effect of different antiseptic substances on the erysipelas agent. In the laboratory setting he could try out as many antiseptics as he wished until he identified the best ones and use those in human surgery. Fehleisen situated his findings explicitly in the context of antiseptic practices, such as antiseptic dressings. He did not use the term 'asepsis'.

Fehleisen's discovery became a milestone in wound infection research. Bergmann announced in his speech in Eisenach that it was now a proven fact that at least one wound disease was directly produced by the invasion of microorganisms of a particular bacterial species. ${ }^{61}$ A commentator in the journal Nature in 1884 saw Fehleisen's experiments and his use of pure cultures as the definitive proof of the aetiology of erysipelas and an exemplary case for such a demonstration in the area of infectious disease. ${ }^{62}$ Koch's procedures started to be regarded as the standard of evidence for work in surgical wound disease. Interestingly, Robert Koch not only provided the instructions for Fehleisen's procedures. The scientist became actually actively involved in the erysipelas work. When Bergmann moved from Würzburg to Berlin, he presented his assistant's research to Koch, and Koch not only approved of this work, but he assumed the maintenance of Fehleisen's cultures, which had been moved along to Berlin. Here, the realignment of surgery and laboratory science took on a very practical dimension. ${ }^{63}$

\section{A Generation of Surgeon-bacteriologists}

The alignment also had a personal dimension. Upon his arrival in Berlin, Bergmann immediately sought to contact Koch, at that time still a 'rising star', at the Imperial Health

\footnotetext{
${ }^{60}$ For this and the following passages, see Friedrich Fehleisen, Die Aetiologie des Erysipels (Berlin: Theodor Fischer, 1883), quotes on pp. 14 and 15.

${ }^{61}$ Bergmann, op. cit. (note 54), 571.

${ }^{62}$ E. Ray Lankester, 'Koch and the Comma-Bacterium', letter to the editor, Nature, December 25 (1884), 168-71.

${ }^{63}$ Fehleisen, op. cit. (note 59), 16.
} 
Office. ${ }^{64}$ The two men entered into an agreeable collegial relationship, as Bergmann's biographer Arend Buchholz claims, which was only limited by Koch's notorious lack of social graces. Bergmann was very enthusiastic about Koch's claim of having found a specific remedy for tuberculosis and was among the first to try out Koch's tuberculin in his hospital. The subsequent catastrophic failure of this project was a bitter defeat for Bergmann, which he never quite overcame. ${ }^{65}$ For many, Bergmann's University Clinic in the Ziegelstrasse was the place where Koch's laboratory methods were transferred to surgery. ${ }^{66}$ It later acquired the reputation of being the 'cradle of the aseptic method' and the 'institution where the technique was executed in an exemplary manner', ${ }^{67}$ as Johann Mikulicz (1850-1905) wrote retrospectively.

Bergmann not only brought new techniques to the renowned institution. His new technique was part of a larger change in modern surgery, a change that is exemplified by the difference between Bergmann and his predecessor Bernhard von Langenbeck (1810-1887). Carl Ludwig Schleich (1859-1922) experienced the transition from the old chief to Bergmann as a young surgeon. In his memoirs he describes how the new director introduced a system of antiseptic drill, elaborated down to the tiniest detail, and implemented with the strictness and pedantry befitting a military institution rather than a civilian hospital. He contrasts Langenbeck's genial, but purely personal, operating skills with Bergmann's precision and thoroughness, which was standardised and thus reproducible by others. ${ }^{68}$ Bergmann introduced a new regime of control that was oriented towards reproducibility of operative results, and more specifically, towards the kind of control that characterised the bacteriology laboratory.

Following his programme, Bergmann systematically recruited surgeons who were versed in the experimental sciences, above all in bacteriology. His assistants were charged with the laboratory work, whereas he himself was responsible for the transfer of the new scientific knowledge into clinical surgery. This was to become the typical pattern in German university surgery of the 1880 s and 90 s, a pattern that led to the rise of a whole generation of bacteriologically trained academic surgeons. ${ }^{69}$ Besides Fehleisen, Hans Schlange (1856-1922) was another example of Bergmann's strategy. Schlange had actually seen the successful application of Neuber's aseptic dressing method when he trained with Esmarch in Kiel, before he joined Bergmann in 1886. To what extent his experience with this kind asepsis contributed to the Bergmann's innovations in wound infection control is an open question. In any case, Schlange was hired by Bergmann for his expertise in bacteriology. As Schlange reported in his recollection of the job interview, Bergmann was extraordinarily enthusiastic about the potential benefits of bacteriology for surgeons, but he was not familiar enough with its methodology to carry

\footnotetext{
${ }^{64}$ Buchholz, op. cit. (note 52), 416.

65 Bergmann's assistant Kurt Schimmelbusch contributed to the disillusionment by furnishing the microscopic evidence that tuberculin did not have the expected effect on tuberculous tissue. Buchholz, op. cit. (note 52), 454-6; Gradmann, op. cit. (note 20), 187-8.

${ }^{66}$ See eg. Paul Leopold Friedrich, Das Verhältnis der experimentellen Bakteriologie zur Chirurgie. Antrittsvorlesung gehalten am 10. Juli 1897 in der Aula der Universität Leipzig (Leipzig: Wilhelm Engelmann, 1897), 26-7.

67 J. Mikulicz, 'Ueber Versuche, die "aseptische" Wundbehandlung zu einer wirklich keimfreien Methode zu vervollkommen', Deutsche medizinische Wochenschrift, 33 (1897), 409-13: 409.

68 Schleich, op. cit. (note 53), 168-70; Buchholz, op. cit. (note 52), 428-36.

${ }^{69}$ See eg. L. Rydygier, 'Einige Bemerkungen über die auf unserer Klinik geübte Methode der Anti- und Asepsis', Wiener klinische Wochenschrift, 11 (1898), 993-6.
} 
out the bacteriological research himself. He thus assigned Schlange, who had some laboratory experience to his name, to conduct bacteriological investigations of wound dressings. In this research, Schlange found that sublimate, which, following Koch's 1881 study, was considered the best antiseptic substance, in fact lost its antibacterial qualities upon contact with blood. This finding contributed to the further reorientation of the Ziegelstrasse hospital away from the use of antiseptics, towards other principles of wound infection control - and added a bacteriological vindication to Neuber's clinically based renouncement of antiseptics. ${ }^{70}$

However, the adoption of bacteriology was by no means restricted to Bergmann's hospital. A whole generation of German-speaking academic surgeons was shaped by the connection with the bacteriological laboratory. It was a time when, after 1885, Koch had succeeded in installing many of his followers in academic key positions. Bacteriology had established itself as a teaching subject and was in high demand among the new generation of future doctors. ${ }^{71}$ In this context a number of German-speaking surgeons built their academic careers on their bacteriological research. The Swiss Karl Garrè (1857-1927), for example, completed his postdoctoral degree, habilitation, in Basle in 1886 in bacteriology and surgery in combination. In 1884 the head of surgery at the city's Bürgerspital, August Socin (1837/99), had established a bacteriological laboratory in Basle and put his assistant Garrè in charge of it. The young surgeon used Koch's methods to investigate a whole range of surgical topics in connection with antisepsis. ${ }^{72}$ In 1885 he published a typically Kochian study with pure cultures and inoculation experiments on the topic of bone infection (osteomyelitis) taking Fehleisen's erysipelas study as his model. Apart from animals, he also used himself as an experimental subject and inoculated bacteria from the Staphylococcus culture obtained from osteomyelitis cases into the skin of his own arm. The ensuing putrid infection turned out to be almost uncontrollable. As one result of his studies, Garrè modified Koch's one species-one disease model, finding the Staphylococcus he had isolated from osteomyelitis cases also caused other purulent infections, such as furunculosis and panaritium - which could sometimes even be induced by other cocci species too. The apparent specificity of erysipelas described by Fehleisen thus seemed to be an exceptional case, he concluded. ${ }^{73}$ Garrè went on to become one of the most important surgeons in the German-speaking world. ${ }^{74}$

In Berne, the later Nobel laureate Theodor Kocher (1841-1917) had been one of the earliest proponents of Lister's antisepsis on the continent. ${ }^{75}$ In 1886 he had his private assistant Ernst Tavel (1858-1912) set up a bacteriology laboratory, where the two surgeons cooperated on Koch-style research about practically relevant bacteriological-surgical topics. Tavel did his habilitation on a bacteriological subject in 1889 and started teaching bacteriology and surgery the year after. In the late 1880s and early 1890s, Tavel and Kocher propagated measures such as the sterilisation of instruments in a pressure vapour cooker.

\footnotetext{
70 Schlange's recollections are cited by Buchholz, op. cit. (note 52), 430. About the connection with Neuber, see Konjetzky and Heits, op. cit. (note 50), 31-2.

${ }^{71}$ Berger, op. cit. (note 22), 46.

${ }^{72}$ H. Killian and G. Krämer, Meister der Chirurgie und die Chirurgenschulen im Deutschen Raum (Stuttgart: Thieme, 1951), 166. Gwer Reichen, Die chirurgische Abteilung des Bürgerspitals Basel zur Zeit der Antiseptik (Aarau: Sauerländer, 1949), 58.

73 Dr Garrè, 'Zur Aetiologie acut eitriger Entzündungen', Fortschritte der Medicin, 3 (1885), 165-72.

${ }^{74}$ Killian and Krämer, op. cit. (note 71), 168.

75 Ulrich Tröhler, Der Nobelpreisträger Theodor Kocher 1841-1917. Auf dem Weg zur physiologischen Chirurgie (Basel: Birkhäuser, 1984), 31-5.
} 
Like many surgeons, Kocher adopted various elements of what became the aseptic ritual while continuing to use antiseptics too. ${ }^{76}$

Another bacteriologically active surgeon was Hermann Kümmell (1852-1937) in Hamburg, who was to obtain a leading position in German surgery too. In 1886 Kümmell used Koch's research armamentarium to undermine one of the fundamental tenets of Listerism, the significance of air-borne germs for wound infection. He found that instead of infection through the air, contamination through direct contact was the decisive factor for wound infection and that the use of 'water, soap and brush' was more relevant than antiseptic substances. He admitted that his experiments just provided the scientific justification for a development that was already underway at the time, when most surgeons had already abandoned Lister's spray technique, and air-borne infection was no longer the centre of surgical attention anyway. Kümmell used the word 'aseptic' in the sense of being free of germs. He discussed whether chemical antiseptics should or should not be used, but he did not refer to asepsis as a method characterised by the abandonment of antiseptics.

In order to convince his colleagues of the accuracy of his research findings he used the visualisation aspect of Koch's techniques. For his talk at the German Society for Surgery he even took along his bacterial cultures - a 'fine reagent ... with which we can make all organismic forms in our research objects visible to the eye' - and asked his colleagues to see for themselves that these cultures, which 'meant to represent hands that were disinfected with a solution of carbolic acid and of sublimate' were both full of bacterial growth. He thus directed the surgeons' attention to their hands, which, as he stated, had 'turned to be the object that was the most difficult to disinfect'. Kümmell modified Koch's method in that he deliberately abstained from using pure cultures. These, he argued, would not appropriately represent surgical reality, where germs always occurred in mixtures. ${ }^{77}$ The question of the correct representation of surgical reality in the laboratory was central for the usefulness of laboratory research. It kept coming up on a regular basis and required the constant readjustment of experimental designs.

Kümmell's work called attention to hand disinfection as another topic to be investigated with Koch's tools. For this subject, an 1888 publication by the internist Paul Fürbringer (1849-1930) became canonical. He came up with a standardised procedure in which he first washed his hands with soap, then alcohol, and finally an antiseptic substance. Fürbringer's laboratory-based procedure was quickly adopted as the gold standard of hand disinfection in surgery. Any new suggestions, such as the use of gloves later on, had to be measured against the base line of the Fürbringer method. The method might have been so persistent because any criticism had to satisfy the new laboratory-based standards. These standards demanded 'an experimental arrangement that was transparent and controllable at any time', something that required a high investment in time and effort for anybody who wanted to criticise them, as Fürbringer himself pointed out. ${ }^{78}$

\footnotetext{
${ }^{76}$ Osman Karamehmedovic, Ernst Tavel (1858-1912). Bakteriologe und Chirurg in Bern (Bern: Hans Huber, 1973; ibid., 33-5. Interestingly in 1895 Kocher did not use the term 'asepsis', while in 1899 he did so to characterise his usual anti-infectious procedure: Theodor Kocher and Ernst Tavel, Vorlesungen über chirurgische Infektionkrankheiten (Basle: Sallmann, 1895); Theodor Kocher, 'On Some Conditions of Healing by First Intention, with Special References to Disinfection of Hands', Transactions of the American Surgical Association, 17 (1899), 116-42.

${ }^{77}$ H. Kümmell, 'Die Bedeutung der Luft- und Contactinfection für die praktische Chirurgie', Archiv für klinische Chirurgie, 33 (1886), 531-47. On Kümmell, see Killian and Krämer, op. cit. (note 71), 206-7.

${ }^{78}$ Paul Fürbringer, Untersuchungen und Vorschriften über die Desinfektion der Hände des Arztes nebst Bemerkungen über den bakteriologischen Charakter des Nagelschmutzes (Wiesbaden: J.F. Bergmann, 1888),
} 
Towards the end of the decade, another important element was added to the set of laboratory-based methods of infection control. In collaboration with Koch's hygienic institute, the surgeon Hugo Davidsohn in Berlin examined different ways of making surgical instruments and dressings germ free. As standard for surgical sterility he used the elimination of anthrax spores. This was the point from which any other potentially dangerous bacteria were killed too, as Koch had already suggested in his 1881 study on disinfectants. To reach this point, Davidsohn used the principle of heat sterilisation as it was applied in bacteriological laboratories. He thus implemented Pasteur's proposal of extending the laboratory practice of heat sterilisation into the surgical environment. However, glowing the instruments in a flame, as bacteriologists did, would make them blunt and unusable, the surgeon found. Microbial control would work at the expense of manual control. Therefore, he used another laboratory technique, boiling in water. For the purpose of testing the effects of this method on the usability of sharp instruments, Davidsohn added a sharpness test to his experimental procedures. A microtome that had been boiled provided the same fine cuts as before, he found. As another representation of surgical reality, he conducted his experiments not only with pure cultures but also with real pus. As the best device for boiling instruments he recommended a modified version of the autoclave Koch had in use in his laboratory. Adjusting this laboratory device for the operating room, he recommended its use for dressings, which would not even get wet if stored in a special wire basket. ${ }^{79}$ The autoclave was to become the emblem of the replacement of Lister's antisepsis by the new aseptic surgery. ${ }^{80}$

\section{Asepsis Standardised}

It was in particular Bergmann's assistant Kurt Schimmelbusch (1860/95) who helped to make the term 'asepsis' a widespread and powerful means of branding the new approach. Because of this he is often counted among the inventors of asepsis. ${ }^{81}$ Impressed by the young surgeon's excellent bacteriological work on the causation of furuncles, Bergmann hired Schimmelbusch in 1889. Schimmelbusch had started working in the bacteriological laboratory as an undergraduate in Göttingen, where he had even identified the causal agent of an animal disease, and had stayed faithful to the field ever since. ${ }^{82}$ His special achievement was to integrate and standardise the various innovations of the previous decade introduced at Bergmann's clinic into a formalised system, an 'aseptic apparatus', as he called it. ${ }^{83} \mathrm{He}$ included elements such as Koch's and Davidsohn's use of the

quote p. 3; Paul Fürbringer, 'Zur Desinfection der Hände des Arztes', Deutsche medizinische Wochenschrift, 14 (1888), 985-7; Paul Fürbringer and Dr Freyhan in Berlin, 'Neue Untersuchungen über die Desinfection der Hände', Deutsche medizinische Wochenschrift, 23 (1897), 81-5. On Fürbringer, see Julis Leopold Pagel, Biographisches Lexikon hervorragender Ärzte des neunzehnten Jahrhunderts (Berlin, Wien: Urban und Schwarzenberg, 1901), 567-8.

${ }^{79}$ Hugo Davidsohn (I. Aus dem hygienischen Institut zu Berlin), 'Wie soll der Arzt seine Instrumente desinficiren?' Berliner klinische Wochenschrift, 25 (1888), 697-703. Hugo Davidsohn, Arzt in Berlin, 'III. Die Benutzung des Koch'schen Dampfapparats für die Sterilisierung von Verbandstoffen', Berliner klinische Wochenschrift, 126 (1889), 956-7. Davidsohn did not use the word 'asepsis' but presents his method of sterilisation and disinfection as a contribution to a new kind of antisepsis based on Koch's bacteriology.

${ }^{80}$ Worboys, op. cit. (note 2), 186.

${ }^{81}$ Erwin Ackerknecht, A Short History of Medicine (Baltimore: John Hopkins University Press, 1982), 191.

${ }^{82}$ Ernst von Bergmann, 'Nachruf an Dr Kurt Schimmelbusch', Berliner klinische Wochenschrift, 32 (1895), 730-1: 730.

${ }^{83}$ Curt Schimmelbusch, Anleitung zur Aseptischen Wundbehandlung (Berlin: Hirschwald, 1892), 161. 
elimination of anthrax spores as a measure for successful disinfection, Fürbringer's hand disinfection, and the heat sterilisation of instruments and dressings. All the elements of this package were based on Kochian bacteriology. Schimmelbusch's Guide to Aseptic Wound Treatment, first published in 1892, rapidly became the authoritative reference work for the new technology. By 1895 it had been translated into almost all European languages and its procedures had spread worldwide, as Bergmann claims in his obituary upon his assistant's untimely death in that year. ${ }^{84}$

With Schimmelbusch's guide, the word 'asepsis' seemed to have spread as an umbrella term for all the bacteriology-based innovations of the preceding decade. Even though Neuber had already used the word in the 1880s to distance himself from Lister, it did not take on. It took until 1890 for Bergmann to use the term in the new sense when, at the tenth International Medical Congress in Berlin he claimed to have replaced 'antisepsis' by 'asepsis' in his hospital in the preceding two years. ${ }^{85}$ The word started to turn up frequently in the German-speaking literature after Schimmelbusch publicised it in his Guide of 1892. The novelty of this usage can be seen by the fact that it needed to be explained to readers outside of Germany by the translator of Schimmelbusch's Guide in his preface to the English-language version of $1894 .{ }^{86}$ Schimmelbusch not only spread the term that had originally been coined by Neuber, he also included Neuber's method in its genealogy, even though the Kiel surgeon had rejected the laboratory as an authoritative source of knowledge.

For Schimmelbusch, 'asepsis' denominated a new stage of infection control in surgery. The term emphasised the novelty of the new techniques but at the same time maintained the connection with Lister. In his guide, Schimmelbusch reiterated Bergmann's programme of active control. ${ }^{87}$ Asepsis would help surgeons finally to meet the expectation raised by the introduction of antisepsis a couple of decades before. Before turning to the practical part, Schimmelbusch reviewed the fundamental changes antiseptic practices had gone through in recent years, in the course of which, as he phrased it, many of Lister's assumptions had yielded to the results of exact research. Thus his antiseptic predecessors had actually not measured the effect of supposedly antiseptic substances on germs. Instead they had inferred their effect from their ability to neutralise bad smells. The result was uncertainty: 'If one looks back to the introduction and the development of antiseptic wound irrigation', he concluded, 'one has to admit that it has never been a secure doctrine in surgery, based on experiment and experience, but only the result of hypotheses and a matter of belief' ${ }^{88}$ The distinction between the old antisepsis and the new asepsis here clearly serves polemical purposes.

In his report on the aseptic routine in Bergmann's clinic of 1891 he described the increasing impact of Robert Koch's work on surgery: 'The streams of antiseptic solutions that used to flow in the operating rooms only a couple of years ago are running dry, and instead of germ-killing agents autoclaves and boiling apparatus have found their way into the hospitals. ${ }^{89}$ It was Koch's influence, Schimmelbusch argued, that convinced

\footnotetext{
${ }^{84}$ Schimmelbusch, op. cit. (note 82); Bergmann, op. cit. (note 81).

85 Ernst von Bergmann, 'De l'asepsie substituée à l'antisepsie', La semaine médicale, 10 (1890), 303.

${ }^{86}$ Alfred Theodore Rake, 'Translator's preface', in Curt Schimmelbusch (ed.), The Aseptic Treatment of Wounds, translated from the 2nd German edn (London: Lewis, 1894), vii.

87 Schimmelbusch, op. cit. (note 82), 3.

88 Schimmelbusch, op. cit. (note 82), 166.

${ }^{89}$ Curt Schimmelbusch, 'Die Durchführung der Asepsis in der Klinik des Herrn Geheimrath von Bergmann in Berlin', Archiv für klinische Chirurgie, 42 (1891), 123-71.
} 
surgeons of the germ theory and the use of antibacterial measures. The bacteriologist's work had refuted the tenacious view that wound infections represented some general disease of the whole organism and the effect of a bad constitution. It had also overthrown the related belief that microorganisms were present in the healthy body, and that the wound was only the occasion for them to unfold their effect. ${ }^{90}$ It was only due to Koch's systematic method, Schimmelbusch believed, that these notions could be finished off and an absolutely certain basis for the prevention of wound infection be established. His prime example was Fehleisen's erysipelas study, which he described in detail, even reproducing one of Koch's original images of the erysipelas pathogen invading living tissue - similar to Figure 1 above.

Giving a nice example of the Kochian approach, Schimmelbusch asserted that even though the human organism was not a test tube filled with agar-agar or coagulated blood serum, contact with an infectious agent had the same consequences for the culture medium as for the organism: the erysipelas Streptococcus infected the human body from the smallest wound as certainly as it infected the gelatine or the serum in the test tube. ${ }^{91}$ This reflects, of course, Koch's notion of the body as a passive reactor to aggressive invaders, and it had important implications for surgical practice, which Schimmelbusch described in the following passage.

Everyone who is familiar with bacteriological investigations knows what an extraordinary effort and special diligence it required to avoid inadvertent infection of nutrient solutions and nutritious substrates and how it still occurs despite all precautions; even less can one expect the absolute containment of germs with certainty in an operation, where so numerous different and uncontrollable factors are involved. ${ }^{92}$

Surgeons in their operating rooms had to be as diligent as scientists in their laboratories. In order to keep infectious agents out of the wounds, they had to recreate laboratory conditions in their operating rooms, which was a precarious and not always successful task. Replicating the controlled conditions of the laboratory required utmost thoroughness in disinfection; an objective that Schimmelbusch, like others, thought could be accomplished best with heat sterilisation. On the basis of bacteriological tests and considerations about the preservation of instruments Schimmelbusch recommended boiling them in soda water. ${ }^{93}$ Besides instruments, dressings were particularly vulnerable to contamination. Often supposedly sterile material from pharmacies and factories was found to be heavily contaminated upon bacteriological examination. The dressing material 'has to endure a whole series of infection hazards ... until it arrives at its destination point, the patient's wound'. ${ }^{94}$ Schimmelbusch's solution to that control problem was the sterilisation of the dressings on a daily basis shortly before the operation. After steam sterilisation, the material stayed in the same container until used. For a suitable device he looked to the laboratory. For small-scale conditions, he writes, the steam cooker that Koch had developed for his lab was sufficient. For surgical routine in larger institutions, numerous modified versions of this device had been suggested in the surgical literature. Schimmelbusch's own version of the cooker became a widely used standard device and emblematic for aseptic surgery.

\footnotetext{
${ }^{90}$ Schimmelbusch, op. cit. (note 82), 17.

91 Schimmelbusch, op. cit. (note 82), 79.

92 Schimmelbusch, op. cit. (note 82), 161.

93 Schimmelbusch, op. cit. (note 82), 49-67.

94 Schimmelbusch, op. cit. (note 82), 81.
} 


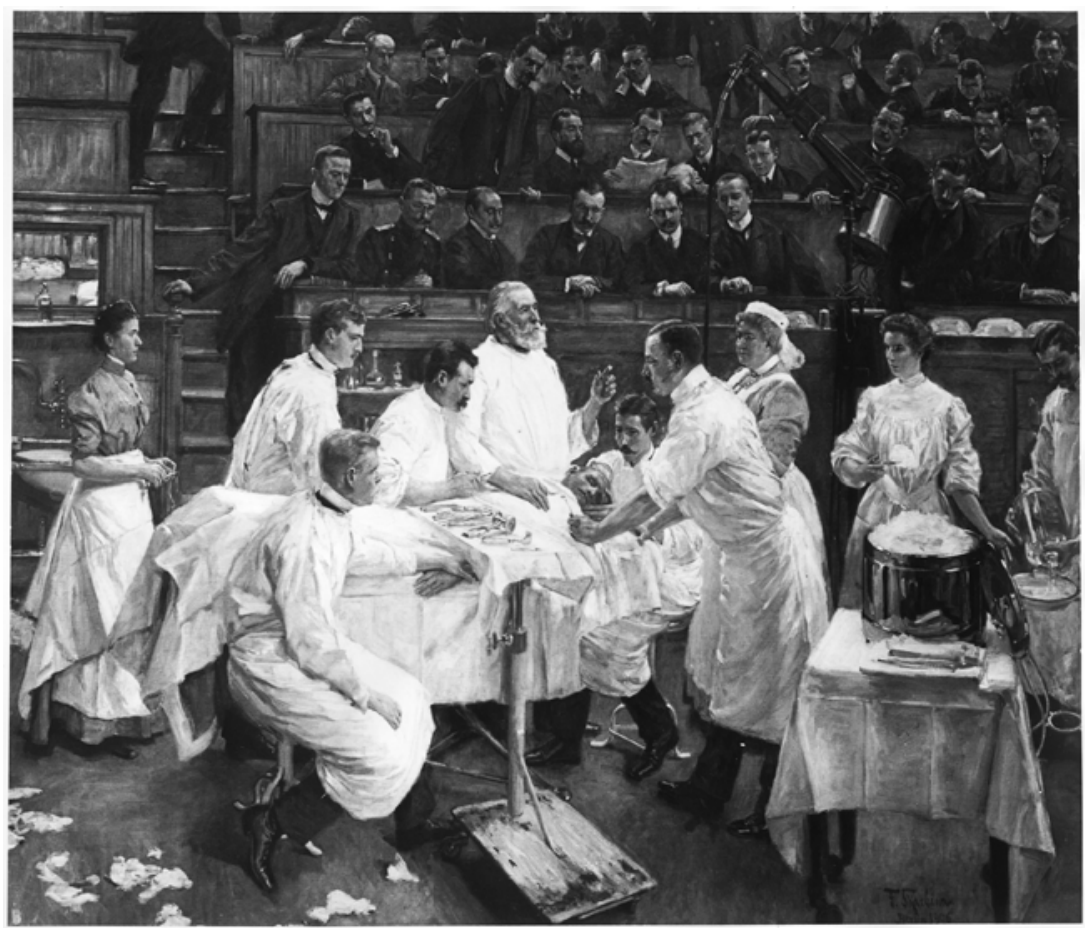

Figure 2: The local culture of asepsis at Ernst von Bergmann's hospital in Berlin. Painting of 1906 by Franz Skarbina (1849-1910), bpk, Berlin painting missing since 1945. (c)Art Resource, NY, image reference ART422595.

The practices that Schimmelbusch subsumed under the heading 'asepsis' were adopted simultaneously in different places in the German-speaking world. Standardisation was supported by the use of the same devices, such as the Schimmelbusch drum, and by using the same textbooks, such as his Guide. The urge with which Schimmelbusch, and other elite surgeons, asked their colleagues to adopt aseptic principles is an indirect indicator of resistance or at least inertia in the surgical profession. In any case, the individual surgical centres differed considerably in their techniques - gloves and masks, for example, were used in some places but not in others. One can speak of veritable local cultures of asepsis. A painting of 1906 by Franz Skarbina (1849-1910) (Figure 2) shows how Bergmann's clinic represents one such local culture.

The work was commissioned for Ernst von Bergmann's twenty-fifth anniversary as chief surgeon at the Ziegelstrasse Clinic in Berlin. Bergmann died before the picture was finished - followed by the painter not long afterwards. We see the master in a slightly idealised portrait teaching during an operation. The artist shows the instruments on a tray ready for use. On the right-hand side a Schimmelbusch drum takes a prominent place. Everybody involved in the operation wears white surgical gowns, which creates a contrast to the dark tones of the background. There are no surgical gloves shown, nor are masks or hats worn in this image. The scene is set in a semi-public operating theatre. The operation takes place in front of an audience of interested colleagues in street clothes. This was at a time when many of Bergmann's colleagues, in response to a perceived crisis of aseptic 
surgery, had moved to smaller operating rooms and wore masks and gloves on a routine basis.

\section{Crisis}

In the late 1890s, commentators reported a growing nervousness among surgeons, who, with increasing demands on the perfection of wound treatment, started feeling insecure about their practices. ${ }^{95}$ Since the publication of Schimmelbusch's work at the beginning of the decade, surgeons had noticed that even this system would not guarantee that the operation wound stayed germ free, Mikulicz claimed in $1898 .{ }^{96}$ Even worse, he added, the transition from antisepsis to asepsis had actually not improved the outcome of wound treatment, thus putting the whole project of asepsis into question. Even at Bergmann's department, he argued, one could see occasional failures. ${ }^{97}$ Therefore, many investigators were assiduously searching for weak points in the current methods of wound treatment. ${ }^{98}$ One of the reasons for surgeons' uncertainty goes back to the fact that asepsis was difficult to monitor. It depended on an absence, not a presence. In antisepsis, surgeons knew when they had disinfected an object. It was an active act and thus much easier to control. This did not apply to asepsis which was much more elusive. Therefore, Heinrich Helferich (1851-1945), for example, preferred using disinfected gloves over sterilised ones, because he 'wouldn't have the same degree of control with the latter'. 99

Johann von Mikulicz-Radecki belonged to the new generation of academic surgeons who had grown up with bacteriology. Head of the surgery department of the University of Breslau since 1890, he was a student of Billroth's and became an extremely influential surgeon - one of the 'kings of the discipline', as historians characterised him. ${ }^{100}$ His generation was also the one that ingrained the new usage of the term 'asepsis'. Mikulicz presented a new genealogy of asepsis. Its first period, he claimed, was the reception of Lister's original techniques and theories in Germany. This was followed by a period of improvement and simplification, which lasted until bacteriological science demonstrated the errors of Lister's theories and convinced surgeons to replace antisepsis by asepsis ${ }^{101}-\mathrm{a}$ strategy that had led to the current crisis. In the context of this crisis, antisepsis and asepsis were pitched against each other as alternative, and often mutually exclusive, strategies of wound infection control. ${ }^{102}$

\footnotetext{
95 Professor Dr Landerer, 'Die Ursachen des Misslingens der Asepsis', Verhandlungen der Deutschen Gesellschaft für Chirurgie, 27 (1898), 38-45: 38 (does not use the term 'asepsis').

96 Mikulicz, op. cit. (note 50), 2.

97 Mikulicz, op. cit. (note 66), 409.

98 Mikulicz, op. cit. (note 50), 3.

${ }^{99}$ Herr Helferich (Greifswald), 'Diskussionsbeitrag', Verhandlungen der Deutschen Gesellschaft für Chirurgie, 27 (1898), 23-25: 24. A similar argument had been brought forward by Lister himself in 1891, see Pennington, op. cit. (note 11), 39 .

100 Killian and Krämer, op. cit. (note 71), 187.

101 Mikulicz, op. cit. (note 50), 1-2.

102 Friedrich declared his research to be about the question of whether surgeons should use antisepsis or asepsis. Professor Dr P.L. Friedrich, 'Die aseptische Versorgung frischer Wunden, unter Mittheilung von TheirVersuchen über die Auskeimungszeit von Infectionserregern in frischen Wunden', Verhandlungen der Deutschen Gesellschaft für Chirurgie, 27 (1898), 46-68: 47. For a similar British example in the same time period, see Worboys, op. cit. (note 2), 190. The terms became so polemically charged that Neuber felt he should come to the defence of the 'old antisepsis' against the disparaging remarks against it in an 1898 discussion, see Herr Neuber (Kiel), 'Diskussionsbeitrag', Verhandlungen der Deutschen Gesellschaft für Chirurgie, 27 (1898), 19-21. Some surgeons explicitly rejected the term 'aseptic wound treatment', for example Anton Wölfler in
} 
In several publications in 1897 and 1898 Mikulicz discussed how the switch from antisepsis to asepsis had upped the ante. Antisepsis had been relatively forgiving. The antiseptic approach followed what Mikulicz called the 'pest control principle' ['Kammerjägersystem'] and killed germs indiscriminately. By contrast, in asepsis with its much more targeted approach, 'the smallest mistake in wound treatment would come back to haunt the surgeon in a much more serious way than in the past'. ${ }^{103}$ With asepsis it was all or nothing. Confronted with imperfections of current aseptic practices, Mikulicz felt he either had to give up the aseptic principle altogether and return to the old antiseptic practices, or he had to work on the refinement of asepsis 'to its uttermost consequences'. ${ }^{104}$ He went for the latter choice. When he discussed the varying quality of surgeons' hand disinfection procedures he framed the problem in terms of responsibility and asked: 'Are we permitted to let the welfare and life ['Wohl und Leben'] of the sick entrusted to us depend upon such uncontrollable contingencies?' And he went on to add a fundamental thought about risk control and technology in 'the increasingly technical art of surgery'. 'In the same way as in other areas of technology - in the operation of railways, in mining and in the metal industry - it can be demanded of us that we perfect as far as possible the arrangements for the safety of the humans that are entrusted to us' ${ }^{105}$ Obviously, for him, surgery was one of the modern technologies that came with a particular risk potential, comparable to modern industry and transport.

In order to live up to that responsibility, control was of the essence: All objects used in an operation - swabs, compresses etc. - were possible sources of contamination. It was essential to have absolute certainty about their perfect sterility. Instruments had to be cooked before the operation under the surgeon's control. Many surgeons had moved the steam cookers either into the operating room or arranged things in 'a way that swabs, dressing material etc. would be taken out of the cooker and passed on to the operating room through an opening in the wall in front of the surgeon's eyes' ${ }^{106}$ For monitoring the sterilisation process, Mikulicz used a paper strip with a chemical that changed its colour when it was exposed to a certain temperature for a certain time. Laboratory experiments had shown him that even the most resistant germs - spores of anthrax and germs occurring in garden soil - were killed before the strip had undergone total discoloration. ${ }^{107}$ This device replaced the evasive control of humans with a more reliable chemical control principle, as Garrè pointed out: 'If we have well-trained, trustworthy staff at our command, or if malfunction of our sterilisation devices can be excluded, there will be hardly any danger. But if the machines fail, and the personnel lacks the right judgement, then this kind of control becomes important.' 108

To improve the aseptic method, Mikulicz judged it to be 'indispensable to get in touch with a professional bacteriologist, who in all these things sees clearer and less biased than we surgeons.' He thus started working with Carl Flügge (1847-1923), the

1897, who wanted to replace it by the term 'atoxic antisepsis', see A. Wölfler, 'Ueber Operations-Handschuhe', Beiträge zur klinischen Chirurgie, 19 (1897), 255-9: 255.

103 Mikulicz, op. cit. (note 66), 411.

${ }^{104}$ Mikulicz, op. cit. (note 66), 411.

105 Mikulicz, op. cit. (note 66), 411.

${ }^{106}$ Mikulicz, op. cit. (note 50), 5. This was something that Schimmelbusch had recommended in his Guide, Schimmelbusch, op. cit. (note 82), 157.

107 Mikulicz, op. cit. (note 50), 5.

108 Herr Garrè (Rostock), 'Diskussionsbeitrag', Verhandlungen der Deutschen Gesellschaft für Chirurgie, 27 (1898), 22-3: 22. 
local hygienist at Breslau, who was also an expert in Kochian bacteriology. Mikulicz investigated wound infection control in Flügge's laboratory. Conversely, Flügge joined the surgeon in his operating room to evaluate the aseptic measures to be introduced there. ${ }^{109}$ This relationship is a nice illustration of the realignment of laboratory science and surgery. Surgeons and bacteriologists worked side by side. They took problems from surgical practice and translated them into laboratory models. They would then work on solving these problems in the artificial world of the laboratory, where phenomena are easier to control and where they can try out things without exposing patients to risk. In a next step, they extended the laboratory conditions to the operating room by adjusting surgical practices in accord with their laboratory findings.

Laboratory examinations showed that the number of air-borne germs in a semi-public surgical theatre was more than ten times higher than in an isolated, aseptic operating room. Air-borne infection was thus not completely negligible, even in asepsis. Therefore, Mikulicz recommended limiting the number of spectators and had them wear long linen gowns and rubber shoes. Flügge drew his attention to another possible gap in sterility, a phenomenon he called 'droplet infection'. The hygienist had found in his experiments that even during calm speaking, bacteria from the mouth cavity were distributed in the surrounding space through little droplets of saliva and mucus. He had determined the bacterial species and measured the numbers of bacteria spread in this way. In reaction to these findings, Mikulicz started wearing facemasks covering nose, mouth and beard. $\mathrm{He}$ also reported about the bacteriological examination of the patient's skin in the operation area from where germs could indirectly be transferred to the wound and tackled this problem with covers of sterile material, as Schimmelbusch had already recommended in 1892. ${ }^{110}$ Schimmelbusch had also discussed the clothing issue in his Guide. He had recommended long gowns made of white linen, sterilised in steam shortly before the operation and demanded 'the staff of any larger surgical establishment to be effectively uniformed and be amply equipped with aprons and coats'. Most importantly, nobody involved in an operation could wear their day-to-day clothing but had to don a special outfit. ${ }^{111}$ Many of the elements of today's surgical paraphernalia were thus added in the laboratory-driven search for weak points in the aseptic all-or-nothing system of preventing wound infection.

Not all surgeons were convinced of the usefulness of the kind of aseptic surgery that dominated the German discussion. Some considered the aseptic outfit, with its gloves, mask and hat excessive. ${ }^{112}$ Alexander Fraenkel (1857-1941), a surgeon and from 1896 editor-in-chief of the renowned Wiener klinische Wochenschrift, scorned it in 1898 as 'a whole surgical costume with a bonnet, mouth mask and veil, devised under the slogan of total wound sterility'. The exclusive emphasis on germs embodied in these precautions he judged unscientific, and he criticised the negligence of the role of the host organism and its tissues. Local wound conditions needed particular attention, he thought. Bruises, foreign

${ }^{109}$ Mikulicz, op. cit. (note 66), 412; Mikulicz, op. cit. (note 50), 3; Johann Mikulicz, 'Das Operiren in sterilisirten Zwirnhandschuhen und mit Mundbinde', Centralblatt für Chirurgie, 24 (1897), 713-19: 716. On Flügge, see Berger, op. cit. (note 22), 45-6. Flügge's compendium, Dr C. Flügge, Grundriss der Hygiene für Studierende und Praktische Ärzte, Medicinal- und Verwaltungsbeamte (Leipzig: Veit, 1889), was completely based on Kochian bacteriology.

${ }^{110}$ Mikulicz, op. cit. (note 66), 412; Mikulicz, op. cit. (note 50), 3; Mikulicz, 'Das Operiren', ibid., 716; Schimmelbusch, op. cit. (note 82), 153.

111 Schimmelbusch, op. cit. (note 82), 153-7, quote p. 158.

112 Eg. Rydygier, op. cit. (note 68), 995. 
bodies, excessive blood accumulation would all lead to a 'disposition for infection'. Very frequently, he argued, wounds healed perfectly despite the presence of enormous amounts of germs. It was therefore wrong to just focus on germs and neglect clinical observation as a valid source of knowledge. 'Asepsis', he posited, 'means that wounds healed without pus, but not necessarily without germs'. ${ }^{113}$ The widespread use of the word to denominate a method he found unfortunate. Fraenkel thus opposed the realignment of surgery and laboratory science as well as the practical innovations it entailed, along with the meaning the word 'asepsis' was given.

All of these discussions point to the fact that the introduction of laboratory-inspired control principles in surgical practice was by no means the implementation of a preconceived plan. Despite programmatic statements, such as Bergmann's, in practice we can see a process of tinkering, trial and error and constant adaptation, in which surgeons grappled with the concrete problem of contamination and wound infection. Mikulicz asked his readers in 1897 to bear in mind that the discussions on techniques of infection control were far from being terminated. Rather, the issue was in full development: 'Many of the measures suggested so far', he predicted, 'might be exaggerated and ... they might be dropped again later on. Some measures are - that much we can already say - erroneous and have to be replaced by better ones' ${ }^{114}$

\section{Towards Complexity}

In the meantime, bacteriology had become more complex. While Koch's success reached its apogee in the 1890s, other scientists had started adding another layer of complexity to the master's original concept of a simple bacterial invasion. They became more interested in variations of the virulence of the infectious agent and the susceptibility of the host organism. So, on the one hand, the Hamburg cholera epidemic of 1892 had been an opportunity for Koch to demonstrate the success of his simplistic strategy of pursuing the infectious agent 'into its remotest nook' - a strategy that had found its exact parallel in surgical anti- and asepsis. But in the same year Koch's nemesis, the hygienist Max von Pettenkofer (1818-1901), gave a very different signal when he conducted his famous self-experiment of drinking a cholera culture thought to be viable without getting sick. ${ }^{115}$ Pettenkofer's experiment marks the comprehensive transformation and broadening of the bacteriological thought style in the period between 1890 and 1914, as described by Silvia Berger. ${ }^{116}$

According to Andrew Mendelsohn, critics found that 'the old bacteriological laboratory now seemed a place where unnatural events had been staged, bearing little or no relation to the actual behaviour of infection' ${ }^{117}$ The experimental bacteriology's original recipe for success, namely its simplicity and artificiality, had become a central point of criticism. Critics demanded more room for disease factors that could not be represented in a vial

\footnotetext{
113 Alexander Fraenkel, 'Congresseindrücke vom 27. Congress der deutschen Gesellschaft für Chirurgie in Berlin', Wiener klinische Wochenschrift, 21 (1898), 419-21: 420; Alexander Fraenkel, 'Einige Bemerkungen über Neuerungen der “aseptischen” Technik', Wiener klinische Wochenschrift, 10 (1897), 653-5.

114 Mikulicz, op. cit. (note 50), 36.

115 J. Andrew Mendelsohn, 'Cultures of Bacteriology. Formation and Transformation of a Science in France and Germany, 1870-1914' (unpublished PhD dissertation: Princeton University, Princeton 1996), 442-75.

116 Berger, op. cit. (note 22), 91.

117 J. Andrew Mendelsohn, 'From eradication to equilibrium: how epidemics became complex after world war I', in Christopher Lawrence and George Weisz (eds), Greater than the Parts. Holism in Biomedicine, 1920-1950 (New York, Oxford: Oxford University Press, 1998), 303-31.
} 
or on a culture plate, things like patients' disposition, their social situation, etc. ${ }^{118}$ The criticism was in part due to the accumulation of facts that didn't match the simple Kochian precepts, such as the existence of pathogenic microorganisms in healthy carriers. Doctors and scientists had to look for additional factors to explain them. One of them was the defence mechanism of the patient's body. Another one was the variability of bacteria. ${ }^{119}$

The new complexity was also reflected in the bacteriological work done by surgeons. Alexander Fraenkel's criticism points in that direction, especially since he referred to one of the most important bacteriology dissidents of the time, Ferdinand Hueppe (1852-1938), as a new authority. ${ }^{120}$ A good example of a surgeon who included the new view in his work is Paul Leopold Friedrich (1864-1916), who, like others, had based his career as an academic surgeon on bacteriology. Friedrich had actually worked with Robert Koch himself. He was assistant physician at the pathological-bacteriological department of the Imperial Health Office from 1889 to 1891, where he conducted a variety of bacteriological studies. He contributed to Koch's experiments on tuberculin, conducted fully fledged bacteriological studies on the cholera bacillus, and developed a heating device for microscopes for special bacteriological examinations. ${ }^{121}$ Friedrich was as much a bacteriologist as he was a surgeon. Subsequently he became an assistant at the surgical university clinic in Leipzig, where he completed his habilitation on a bacteriological topic and went on to posts as chief surgeon at the universities of Greifswald, Marburg and Königsberg.

Friedrich's main contribution to aseptic surgery was his research on the spread of infection from the infected wound to the rest of the body, published in 1898. Even though there was general consensus about the superiority of asepsis in surgical operations, some prominent surgeons were suggesting that, for accidental wounds, one should return to antiseptic techniques - which were seen as an alternative to, not a part of asepsis - as the only means of preventing the spread of the wound infection and generalised septic disease. Based on the results of his experimental and clinical investigations, Friedrich was able to counter this suggestion and recommend cutting out the wound instead of using antiseptics.

In his discussion of the previous work, Friedrich criticised the relatively large corpus of Koch-style work on the topic as being too simplistic. For example, researchers had used pure cultures, which, for all their persuasiveness, misrepresented the complicated surgical reality and led to erroneous conclusions. Investigators, he held, should develop more sophisticated laboratory models, which represented clinical reality more accurately. They should use fresh, uncultivated infectious material in order to obtain the correct degree of virulence; and they should also choose an animal species that reflects the human susceptibility to the infection. By explicitly taking the variability of bacterial virulence and host susceptibility into consideration, Friedrich went beyond the simple invasion model of early bacteriology. However, even the best experimental setup had limited predictive

\footnotetext{
118 Representation, see Berger, op. cit. (note 22), 94, who cites Ferdinand Hueppe (1852-1938), an early 'dissident bacteriologist'. On the relationship of practical medical problems with the bacteriological reorientation, see Amsterdamska, op. cit. (note 41), 671-5.

119 Berger, op. cit. (note 22), 91-130.

${ }^{120}$ Fraenkel, 'Einige Bemerkungen', op. cit. (note 112), 654; on Hueppe as a dissident, see Berger, op. cit. (note 22), 92-6.

121 Pagel op. cit. (note 77), 553-4; Paul Friedrich, 'Vergleichende Untersuchungen über den Vibrio Cholerae asuaticae (Kommabacillus Koch), mit besonderer Berücksichtigung der diagnostischen Merkmale desselben', Arbeiten aus dem Kaiserlichen Gesundheitsamte, 8 (1893), 87-134; Paul Friedrich, 'Eine Heizvorrichtung des Mikroskops zu bakteriologischen Untersuchungen', Arbeiten aus dem Kaiserlichen Gesundheitsamte, 8 (1893), $135-9$.
} 
powers, he pointed out when discussing the regularities of the spread of bacterial infection: "we are dealing here with a biological law that only gives us an approximate time limit, because, as with everything that lives, varying factors, which cannot be discussed here, can have a partially unpredictable influence'. ${ }^{122}$

Friedrich addressed this issue also in the talk on the relationship of surgery and bacteriology, the topic he had chosen for his inauguration speech upon his appointment as Extraordinary Professor in Leipzig in 1897. Bacterial virulence and host disposition were important factors to be taken into account, he posited, adding the local wound conditions as another influence on the emergence and spread of wound infections. As an additional modification of the Kochian concept he also stated that Koch's original idea of specificity didn't work entirely in the case of wound infection. In this field, one germ can very well cause various wound diseases, as, vice versa, one disease phenomenon can, in fact, be caused by different germs. Taking these complicating factors into account was important for increasing the laboratory's power of improving outcomes in surgical practice. ${ }^{123}$

\section{Surgery and Experimental Science}

Critics such as Friedrich were right in that the dominance of the laboratory-inspired control strategy relegated other potential factors in wound healing to the background. Adherents of asepsis focused on those factors they were able to control. The attitude is nicely encapsulated in a statement from the British champion of asepsis Charles B. Lockwood (1856-1914) who in 1896 stressed that the 'resistance of healthy living tissues to bacterial invasion cannot be relied upon. It is a thing beyond the control of the surgeon, whilst asepsis is not. No one would exchange a certainty for an uncertainty'. ${ }^{124}$ Surgeons should not reckon too much with uncontrollable factors, such as nature. When Mikulicz referred to nature and the protective mechanisms of the tissues, he only did it to stress 'that this power of the tissue is very limited; the less we expect from it, the surer we can be of success, the more powerful operative surgery is going to be'. ${ }^{125}$ Similarly, Werner Zoege von Manteuffel (1857-1926) invoked the unreliability of the body's defence mechanisms when he argued for the use of rubber gloves. ${ }^{126}$

Asepsis, by contrast, 'gave surgeons the certainty and control that allowed them to accept full technical and moral responsibility for the patient and their treatment. This made surgeons heroic both practically and morally, a position that befitted their professional selfimage as the coming men of medicine', ${ }^{127}$ as Worboys concludes. Hence, in the words of medical historian Peter English, a new breed of surgeons, the radical surgeons, 'were convinced that with the science of bacteriology they could conquer most of man's ills eventually'. ${ }^{128}$ After 1900, the problem of wound infection was largely seen as solved. William Halsted (1852-1922) at Johns Hopkins, for example, stated in 1913 that the

\footnotetext{
122 Friedrich, op. cit. (note 101), 60.

123 Friedrich, op. cit. (note 65), 8-14.

124 Charles Barrett Lockwood, Aseptic Surgery (Edinburgh: Young, J. Pentland, 1896), 96.

125 Mikulicz, op. cit. (note 50), 37.

126 W. Zoege von Manteuffel, 'Gummihandschuhe in der chirurgischen Praxis', Centralblatt für Chirurgie, 24 (1897), 553-6: 554. Specifically on gloves, see Thomas Schlich, 'Manual Versus Aseptic Control: the Controversy about Surgical Gloves in German Surgery in the 1890s', Bulletin for the History of Medicine, 87 (forthcoming).

127 Worboys, op. cit. (note 2), 189.

128 Peter C. English, Shock, Physiological Surgery, and George Washington Crile. Medical Innovation in the Progressive Era (Westport, CT: Greenwood Press, 1980), 30.
} 
medical student now took the achievements of modern surgery and the uncomplicated healing of wounds for granted 'as he does the ability to speak his own tongue'. ${ }^{129}$

The parallel between laboratory practice and aseptic surgery was not lost on contemporaries. Pasteur's recommendation quoted above was not the only proposition to that effect. In Britain, surgeon Charles Keetley (1848-1909) wrote in his textbook as early as 1881 that surgeons 'regard every surgical operation and dressing as a chemicobiological experiment demanding nicety and extreme care', ${ }^{130}$ and Lockwood wrote in 1896: 'An operation founded upon the principles of aseptic surgery is a bacteriological experiment. ${ }^{131}$ In the German-speaking world, Theodor Kocher's student Carl Arndt reported that his teacher treated every operation as a 'bacteriological experiment' ${ }^{132}$ Paul Friedrich wrote: 'Every operative intervention is in a certain sense a new experiment, and an unreliable apparatus can render all of the correctness of the operating experimenter illusionary', ${ }^{133}$ and in 1904 Halsted demanded that 'the hospital, the operating room and the wards should be laboratories...' ${ }^{134}$

This was not just ideological rhetoric. To be sure, there was some symbolic capital to be gained from aligning with laboratory science, and it is correct that, as Worboys claims, 'the adoption of laboratory theories was ...that much easier if surgeons were being persuaded, and even flattered, by the idea that their clinical practice was analogous to laboratory work'. ${ }^{135}$ However, I would argue that the prospect of palpable benefit was more important than questions of prestige. This is why the aseptic surgeons in the 1890 s, as Worboys also points out, 'took the injunction to treat surgical operation as a "bacteriological experiment" literally, as they tested the sterility of everything from the patient's skin to the washings from the operating table with microscopy and cultures' ${ }^{136}$ Equating surgical operations with bacteriological experiments was thus more than mere rhetoric. It reflects the surgeons' efforts of making their treatment results predictable by adopting bacteriologists as their model and using their techniques to subject infectious agents to their control. Therefore, the laboratories we have come across in the context of aseptic surgery - even though they were conceptualised as places apart for their purpose of simplification and control - were also deeply interwoven with practical concerns. They were set up for the goal of mastering wound disease and thus improving surgical outcomes. In the realignment between surgery and laboratory science the laboratory was primarily a source of therapeutic power.

Thus, by the early twentieth century, laboratory science had become more central to surgery than ever before. The adoption of antisepsis and even more so of asepsis, 'had demonstrated the importance of detail, precision, exactness and above all science in surgery', as Worboys notes. ${ }^{137}$ The turn to bacteriology changed surgical practice

\footnotetext{
129 William Stewart Halsted, 'Ligature and Suture Material', Journal of the American Medical Association, 60 (1913), 1119-26: 1119.

130 Worboys, op. cit. (note 2), 182, cites C. Keetley, Index of Surgery (London: Smith, Elder, 1881), 33

131 Lockwood, op. cit. (note 123), 193.

132 Quoted after Tröhler, op. cit. (note 74), 37.

133 Friedrich, op. cit. (note 65), 28.

134 William Halsted, 'The Training of the Surgeon', The Annual Address in Medicine, delivered at Yale University, New Haven, CT, June 27, 1904, first published in Johns Hopkins Bulletin, xv (1904), 267-75, reprinted in William S. Halsted, Surgical Papers (Baltimore: Johns Hopkins Press, 1924), 512-31: 530. For another US example (Arthur Tracy Cabot) see Brieger, op. cit. (note 8), 145.

135 Worboys, op. cit. (note 2), 182

136 Worboys, op. cit. (note 2), 186

137 Worboys, op. cit. (note 2), 192
} 
in profound ways. It enabled a new time regime, allowing for more thorough and technically demanding operations and thus opened the door to new surgical procedures, and subsequently, in an alignment with physiology as another laboratory science, to the reconstruction of body functions, for example through organ transplants. ${ }^{138}$ Early twentieth-century surgeons were thus not only able to built on the technical safety that asepsis provided, they also inherited the strategy of aligning themselves with laboratory science in order to develop a wider range of surgical interventions.

138 Thomas Schlich, The Origins of Organ Transplantation: Surgery and Laboratory Science, 1880s-1930s (Rochester, NY: The University of Rochester Press, 2010). 